987 | Jurna I I de a H u ku m

Vol. 4 No.2 Oktober 2018

$\mathrm{M}$ a gister Hukum Fakultas Hukum

Universitas Jenderal Soedirman

\title{
PERLINDUNGAN HUKUM UNDANG-UNDANG NOMOR 30 TAHUN 2014 BAGI PEGAWAI NEGERI SIPIL YANG DIBERHENTIKAN DAN IMPLIKASINYA TERHADAP KEWENANGAN BADAN PERTIMBANGAN KEPEGAWAIAN Oleh: Arief Rachman Hakim ${ }^{1}$
}

\begin{abstract}
Legal protection of civil servants (PNS) in a dispute over staffing has undergone a paradigm shift with the enactment of Law No. 30 of 2014 on Government Administration (UUAP). The paradigm change then has implications for the authority of the Civil Service Advisory Board (BAPEK). This study aims to analyze how UUAP provide legal protection to the Civil Servant who was dismissed not because of disciplinary punishment of civil servants and what are the implications of the legal protection against BAPEK authority.

This research is normative legal research with qualitative analysis through conceptual approach and legal approach to legal issue which become subject matter in research. Conclusions are drawn deductively through a coherent and systematic description. To support this research, the authors conducted interviews with some of the top officials at BAPEK in Jakarta as complementary data supporting the research analysis.

Based on the results of the study, the enactment of the UUAP which has established the regulation of administrative efforts in Articles 75 to 78, carries the legal consequence that the dismissed civil servant which not due to disciplinary punishment may undertake dispute resolution through administrative measures even though the relevant rules governing it, do not provide a dispute resolution through Administrative effort. This then implies the widespread authority of BAPEK, which before the enactment of UUAP is only authorized to handle administrative appeals of personnel disputes caused by the dismissal of civil servants due to disciplinary punishment.
\end{abstract}

Keywords : administrative measures, legal protection, employment disputes, government administration, administrative appeals.

\begin{abstract}
ABSTRAK
Perlindungan hukum terhadap Pegawai Negeri Sipil (PNS) dalam sengketa kepegawaian telah mengalami perubahan paradigma dengan berlakunya UndangUndang Nomor 30 Tahun 2014 tentang Administrasi Pemerintahan (UUAP). Perubahan paradigma tersebut kemudian berimplikasi terhadap kewenangan Badan Pertimbangan Kepegawaian (BAPEK).

Penelitian ini bertujuan untuk mengidentifikasi, menganalisis dan mendeskripsikan bentuk perlindungan hukum UUAP bagi Pegawai Negeri Sipil yang diberhentikan bukan karena hukuman disiplin dan bagaimana implikasi perlindungan hukum tersebut terhadap kewenangan BAPEK. Penelitian ini adalah penelitian hukum normatif dengan analisis kualitatif melalui pendekatan konseptual dan pendekatan perundang-undangan terhadap isu hukum yang menjadi pokok permasalahan dalam penelitian.

Kesimpulan diambil secara deduktif melalui uraian yang runtut dan sistematis. Guna mendukung penelitian ini, penulis melakukan wawancara kepada beberapa pejabat teras di lingkungan BAPEK di Jakarta sebagai data pelengkap yang mendukung analisis penelitian. Berdasarkan hasil penelitian, berlakunya UUAP yang telah menetapkan pengaturan mengenai upaya administratif dalam Pasal 75 sampai dengan Pasal 78 , membawa konsekwensi hukum bahwa PNS yang diberhentikan bukan karena hukuman disiplin dapat menempuh penyelesaian sengketa melalui upaya administratif meskipun peraturan terkait yang mengaturnya tidak menyediakan sarana penyelesaian sengketa melalui upaya administratif. Hal tersebut kemudian berimplikasi pada meluasnya kewenangan BAPEK, dimana sebelum berlakunya UUAP hanya berwenang menangani
\end{abstract}

${ }^{1}$ Badan Kepegawaian Daerah, Kabupaten Pemalang, 0284321376/081326689000 
banding administratif sengketa kepegawaian yang diakibatkan adanya pemberhentian PNS karena hukuman disiplin.

Kata kunci : upaya administratif, perlindungan hukum, sengketa kepegawaian, administrasi pemerintahan, banding administratif.

\section{A. PENDAHULUAN}

Pertumbuhan

dan

perkembangan hukum administrasi negara berjalan pesat seiring perkembangan tugas-tugas pemerintahan yang tidak semata-mata hanya di bidang pemerintahan saja, melainkan juga tugas-tugas mewujudkan tujuan-tujuan Negara yang diselenggarakan melalui pembangunan nasional. Pembangunan nasional yang bersifat multi dimensi membawa akibat bahwa Negara harus banyak turut campur tangan dalam kehidupan masyarakatnya. Campur tangan tersebut dituangkan dalam ketentuan peraturan perundang-undangan dan dilaksanakan oleh administrasi Negara dalam menyelenggarakan pelayanan publik. Adakalanya, dalam menyelenggarakan pelayanan publik administrasi Negara melakukan "freies ermessen" untuk dapat bertindak atas inisiatif sendiri, meskipun dalam pelaksanaannya haruslah tetap berpedoman pada hukum yang berlaku. $\mathrm{Hal}$ itu berarti dalam mengemban tugasnya secara aktif, administrasi Negara harus dapat menjaga dan menjamin bahwa tindakannya tidak melanggar hak dan kewajiban asasi manusia, juga perlu adanya keseimbangan antara kepentingan Negara dan kepentingan masyarakat atau perorangan. Implikasinya, apabila terjadi sengketa antara administrasi Negara dengan rakyat (masyarakat/perorangan) maka sudah seharusnya diberikan jaminan perlindungan hukum. ${ }^{2}$

Perumusan Undang-Undang Nomor 30 Tahun 2014 tentang Administrasi Pemerintahan (UUAP) yang telah diundangkan pada tanggal 17 Oktober 2014, merupakan bagian dari upaya pembangunan hukum administrasi negara dan sebagai bentuk tanggung jawab negara untuk menjamin penyediaan administrasi pemerintahan yang cepat, nyaman dan murah serta memberikan jaminan perlindungan hukum kepada setiap warga masyarakat. Perwujudan jaminan perlindungan hukum tersebut kemudian dirumuskan dalam ketentuan Pasal 75 ayat (1) UUAP yang menyatakan bahwa:

"Warga masyarakat yang dirugikan terhadap Keputusan dan/atau Tindakan dapat mengajukan Upaya Administratif kepada Pejabat Pemeritahan atau Atasan Pejabat yang menetapkan dan/atau melakukan Keputusan dan/atau Tindakan".

Ketentuan tersebut memberikan arahan bagi warga masyarakat yang

2 Sjachran Basah, 2014. Eksistensi dan Tolok Ukur Badan Peradilan Administrasi di Indonesia, Cet. ke-6, Bandung: PT. Alumni, hal. $2-4$ 
merasa dirugikan kepentingannya oleh

suatu keputusan dan/atau tindakan

badan dan/atau pejabat pemerintahan, dapat menempuh penyelesaian sengketa administrasi pemerintahan melalui sarana upaya administratif sebelum mengajukan gugatan melalui lembaga peradilan.

Sejalan dengan hal itu, ada pendapat yang menyatakan,

"Hakikinya, setiap keputusan TUN dapat diajukan keberatan atau banding administrasi tanpa harus dinyatakan secara eksplisit dalam peraturan perundang-undangan karena kewenangan ini melekat pada pejabat yang menerbitkan keputusan. Alur pikir ini menegaskan Pasal 75 ayat (1) UUAP terhadap berlakunya asas contrarius actus $^{3}$, sekaligus sebagai petunjuk umum bagi warga negara dalam pelayanan publik oleh organ pemerintah. Sebagai petunjuk umum, formulasi "dapat mengajukan upaya administratif" difungsikan untuk mengisi celah manakala peraturan perundangundangan tidak menyediakan upaya administratif. Oleh karena itu, saat peraturan perundang-undangan tidak menyediakan prosedur upaya administratif dan penerima keputusan memanfaatkan upaya administratif

Contrarius Actus dalam hukum administrasi negara adalah asas yang menyatakan badan atau pejabat tata usaha negara yang menerbitkan keputusan tata usaha negara dengan sendirinya juga berwenang untuk membatalkannya, selengkapnya lihat Philipus M. Hadjon dan Tatiek Sri Djatmiati dalam Argumentasi Hukum, Cet. Ke 7, Yogyakarta: Gadjah Mada University Press, 2016, hal. 83 berdasar Pasal 75 UUAP, penerima keputusan terikat untuk melakukan dan menyelesaikan semua upaya administratif yang tersedia sebelum menuju gugatan ke pengadilan." ${ }^{4}$

$$
\text { Sengketa administrasi }
$$

pemerintahan dalam ranah

kepegawaian (sengketa kepegawaian) diatur dalam Undang-Undang Nomor 5 Tahun 2014 tentang Aparatur Sipil Negara (UU ASN) yang membuka peluang terhadap penyelesaian sengketa kepegawaian melalui sarana upaya administratif dengan batasan sebagaimana ditetapkan dalam Pasal 129, sebagai berikut:
(1) Sengketa pegawai ASN diselesaikan melalui upaya administratif;

(2) Upaya administratif sebagaimana dimaksud pada ayat (1) terdiri dari keberatan dan banding administratif;

(3) Keberatan sebagaimana dimaksud pada ayat (2) diajukan secara tertulis kepada atasan pejabat yang berwenang menghukum dengan memuat alasan keberatan dan tembusannya disampaikan kepada pejabat yang berwenang menghukum;

(4) Banding administratif sebagaimana dimaksud pada ayat (2) diajukan kepada badan pertimbangan ASN;

4 Kartono, 2016. Pengaruh UndangUndang Nomor 30 Tentang Administrasi Pemerintahan terhadap Sistem Peradilan Tata Usaha Negara. Makalah disampaikan dalam Diskusi Paralel Bidang HAN Musyawarah Daerah Asosiasi Pengajar HTN-HAN Wilayah Jawa Tengah, Cisarua, Bogor, 14-16 Oktober 2016. 
(5) Ketentuan lebih lanjut mengenai upaya administratif dan badan pertimbangan ASN sebagaimana dimaksud pada ayat (2) dan ayat (4) diatur dengan peraturan pemerintah.

Kemudian ketentuan peralihan dalam Pasal 139 UU ASN menetapkan bahwa, "Pada saat Undang-Undang ini mulai berlaku, semua peraturan perundangundangan yang merupakan peraturan pelaksanaan dari Undang-Undang Nomor 8 Tahun 1974 tentang PokokPokok Kepegawaian (Lembaran Negara Republik Indonesia Tahun 1974 Nomor 55, Tambahan Lembaran Negara Republik Indonesia Nomor 3041) sebagaimana telah diubah dengan Undang-Undang Nomor 43 Tahun 1999 tentang Perubahan Atas UndangUndang Nomor 8 Tahun 1974 tentang Pokok-Pokok Kepegawaian (Lembaran Negara Republik Indonesia Tahun 1999 Nomor 169, Tambahan Lembaran Negara Republik Indonesia Nomor 3890) dinyatakan masih tetap berlaku sepanjang tidak bertentangan dan belum diganti berdasarkan UndangUndang ini."

Oleh karena sampai dengan saat disusunnya penelitian ini, Peraturan Pemerintah sebagaimana diamanatkan oleh Pasal 129 ayat (5) UU ASN belum terbentuk, maka berdasarkan ketentuan Pasal 139 UU ASN tersebut, penyelesaian sengketa kepegawaian melalui banding administratif tetap diselenggarakan berdasarkan Peraturan Pemerintah Nomor 24 Tahun 2011 tentang Badan Pertimbangan
Kepegawaian (BAPEK) yang merupakan amanat dari UndangUndang Nomor 43 Tahun 1999 tentang Perubahan atas Undang-Undang Nomor 8 Tahun 1974 tentang Pokok-Pokok Kepegawaian.

Salah satu kewenangan Badan Pertimbangan Kepegawaian (BAPEK) sebagaimana diatur dalam Pasal 3 huruf b Peraturan Pemerintah Nomor 24 Tahun 2011 tentang Badan Pertimbangan Kepegawaian adalah ${ }^{5}$ "Memeriksa dan mengambil keputusan atas banding administratif dari PNS yang dijatuhi hukuman disiplin berupa pemberhentian dengan hormat tidak atas permintaan sendiri atau pemberhentian tidak dengan hormat sebagai PNS oleh Pejabat Pembina Kepegawaian dan/atau Gubernur selaku wakil pemerintah."

Apabila dikaitkan antara bentuk perlindungan hukum terhadap warga masyarakat sebagaimana dirumuskan dalam Pasal 75 ayat (1) UUAP tersebut dengan tugas dan fungsi BAPEK sebagaimana pasal 3 huruf $b$ tersebut, maka yang menjadi pertanyaan kemudian adalah bagaimana perlindungan hukum UUAP terhadap Pegawai Negeri Sipil (PNS) yang diberhentikan bukan karena dijatuhi hukuman disiplin, karena mengingat salah satu tujuan UUAP adalah memberikan perlindungan hukum terhadap aparatur pemerintahan?

\footnotetext{
5 Lihat Pasal 3 Peraturan Pemerintah Nomor 24 Tahun 2011 tentang Badan Pertimbangan Kepegawaian.
} 
991 | Jurna I I de a Hukum

VoI. 4 No.2 Oktober 2018

$\mathrm{M}$ a gister Hukum Fakultas Hukum

Universitas Jenderal Soedirman

Kemudian, bagaimana kewenangan

BAPEK pasca berlakunya UUAP tersebut?

Berdasarkan tujuan utama yang hendak dicapai dalam penelitian ini, kerangka berfikir penelitian berpijak pada teori tentang HAM dan Negara Hukum sebagai landasan teori utama (grand theory), Teori Hukum Administrasi Negara dan Perlindungan Hukum sebagai landasan teori madya (middle range theory), teori Sengketa Kepegawaian, Upaya Administratif dan BAPEK sebagai landasan teori terapan (applied theory) untuk menjawab rumusan masalah.

\section{B. METODE PENELITIAN}

Penelitian ini adalah penelitian hukum normatif dengan menggunakan analisis secara kualitatif melalui pendekatan konseptual dan perundangundangan terhadap isu hukum yang menjadi permasalahan dalam penelitian.

Pengambilan kesimpulan dilakukan secara deduktif melalui uraian yang runtut dan sistematis. Adapun data lapangan berupa wawancara dengan beberapa pejabat teras di lingkungan Badan Pertimbangan Kepegawaian di Jakarta, hanya sebagai pelengkap/tambahan data yang berguna untuk mendukung analisis dalam penelitian ini.

\section{HASIL DAN PEMBAHASAN}

1. Upaya administratif sebagai bentuk Perlindungan Hukum bagi PNS yang diberhentikan bukan karena hukuman disiplin.
Prinsip perlindungan hukum terhadap warga masyarakat terhadap tindakan pemerintah bertumpu dan bersumber dari konsep tentang pengakuan dan perlindungan terhadap hak-hak asasi manusia, karena menurut menurut sejarahnya di Barat, lahirnya konsep-konsep tentang pengakuan dan perlindungan terhadap hak-hak asasi manusia diarahkan kepada pembatasan-pembatasan dan peletakkan kewajiban pada masyarakat dan pemerintah. Sejalan dengan itu, A.J. Milne dalam tulisannya berjudul, "The Idea of Human Rights" mengatakan, " $A$ regime which protects human rights is good, one which fails to protect them or worse still doesn't acknowledge thier existence is bad". ${ }^{6}$

$$
\text { Perlindungan hak-hak asasi }
$$
manusia dalam sistem hukum the rule of law mengedapankan prinsip equality before the law, sedangkan dalam sistem hukum rechtsstaat mengedapankan prinsip wetmatigheid kemudian menjadi rechtsmatigheid. Konsep sistem hukum the rule of law dan rechtsstaat menempatkan pengakuan dan perlindungan terhadap hak-hak asasi manusia sebagai titik sentral, sedangkan untuk Negara Republik Indonesia yang menjadi titik sentral adalah keserasian dan keselarasan

\footnotetext{
6 Philipus M. Hadjon, 1987. Perlindungan Hukum bagi Rakyat di Indonesia, Sebuah Studi tentang PrinsipPrinsipnya, Penanganannya oleh Pengadilan dalam Lingkungan Peradilan Umum dan Pembentukan Peradilan Administrasi Negara. Surabaya: Bina IImu, hal. 38.
} 
hubungan antara pemerintah dan rakyat berdasarkan asas kerukunan. Negara Republik Indonesia yang menghendaki keserasian hubungan antara pemerintah dengan rakyat dengan mengedepankan asas kerukunan dalam hubungan antara pemerintah dengan masyarakat sehingga terjalin hubungan fungsional yang proporsional antara kekuasaankekuasaan negara dengan rakyat, penyelesaian sengketa secara musyawarah diutamakan, sedangkan peradilan merupakan sarana terakhir. ${ }^{7}$

$$
\text { Kebutuhan akan fungsi }
$$
pengawasan terhadap penyelenggaraan pemerintahan untuk mencegah penyalahgunaan wewenang disatu sisi, dan perlindungan hukum terhadap warga masyarakat disisi lain inilah yang kemudian dielaborasi oleh UUAP melalui pelembagaan sarana upaya administratif yang dapat memberikan jaminan kepastian dan perlindungan hukum sekaligus, baik terhadap warga masyarakat maupun terhadap aparatur pemerintah sehingga terdapat keseimbangan dan keserasian diantara pemerintah dengan rakyatnya yang pada muaranya dapat menciptakan kerukunan dan sinergitas diantara keduanya, sehingga terwujud tata kelola pemerintahan yang baik (good governance).

Berdasarkan konsep negara hukum Indonesia yang berdasarkan Pancasila dan UUD NRI Tahun 1945, maka dalam hal terjadi sengketa antara

\footnotetext{
7 Ibid., hal. 84-85.
}

pemerintah dengan rakyat, prinsip utama yang perlu dikedepankan adalah prinsip penyelesaian sengketa dengan cara musyawarah melalui wadah atau sarana upaya administratif, sedangkan penyelesaian melalui peradilan administrasi dijadikan sebagai sarana terakhir. Penyelesaian dengan sarana upaya administratif diharapkan mampu menjaga dan memulihkan keserasian hubungan antara pemerintah dan warga masyarakat, sehingga kembali tercipta sebuah kerukunan. Dengan demikian upaya administratif akan dirasakan sebagai sebuah kebutuhan karena mampu berfungsi sebagai sarana perlindungan hukum sebagaimana peradilan administrasi. ${ }^{8}$

Berdasarkan hasil wawancara dengan Asisten Sekretaris Badan Pertimbangan Kepegawaian (BAPEK) melalui Surung Hutapea, jabatan Kasubid Pengolahan B4 pada tanggal 10 Mei 2017 di kantor BAPEK di Jakarta, disimpulkan bahwa regulasi dan mekanisme penyelesaian sengketa kepegawaian yang eksis sebelum berlakunya Undang-Uundang Nomor 30 Tahun 2014 tentang Administrasi Pemerintahan (UUAP), belum sepenuhnya memberikan perlindungan hukum (preventif) terhadap PNS yang diberhentikan bukan karena hukuman disiplin karena regulasi-regulasi tersebut tidak menyediakan prosedur penyelesaian melalui upaya

8 SF. Marbun, 2003. Peradilan Administrasi dan Upaya Administratif di Indonesia, Yogyakarta: UII Press, hal. 5960. 
administratif, sehingga membuka peluang munculnya konfrontasi antara PNS dengan Pemerintah di lembaga peradilan administrasi. Hal tersebut menurut pendapat penulis merupakan bentuk pengabaian terhadap eksistensi asas kerukunan antara warga masyarakat/rakyat termasuk didalamnya PNS dengan Pemerintah yang harus mengedapankan musyawarah dalam penyelesaian setiap sengketa melalui lembaga upaya administratif dalam bingkai negara hukum Indonesia yang berdasarkan Pancasila dan UUD NRI Tahun 1945.

\begin{tabular}{llr}
\multicolumn{1}{c}{ Menurut } & Philipus & M. Hadjon \\
perlindungan & hukum & preventif \\
memberikan & kesempatan & kepada \\
masyarakat & untuk & mengajukan \\
keberatan & (inspraak) & atau
\end{tabular}
mengemukakan pendapatnya sebelum suatu keputusan pemerintah mendapat bentuk yang definitif, dalam arti memiliki kekuatan hukum dan dapat dilaksanakan, sehingga dapat mencegah terjadinya sengketa. Perlindungan hukum preventif sangat besar artinya karena dengan adanya perlindungan hukum preventif ini pejabat pemerintahan terdorong untuk bersikap hati-hati dalam mengambil keputusan dan/atau tindakan. ${ }^{9}$

Pemberlakuan

UUAP merupakan langkah revolusioner yang ditempuh oleh negara dalam ranah Hukum Administrasi Negara sebagai

9 Philipus M. Hadjon, Perlindungan Hukum bagi Rakyat..., Op.Cit., hal. 2. upaya untuk mewujudkan perlindungan hukum sekaligus kepada warga masyarakat dan aparatur pemerintah, terutama terkait dengan perlindungan atas hak-hak untuk didengar pendapatnya (right to be heard) melalui lembaga upaya administratif, sebagaimana diatur dalam Pasal 75 ayat (1) UUAP.

Mendasarkan pada beberapa hal di atas, sudah sepatutnya bahwa penyelesaian sengketa administrasi pemerintahan dan/atau sengketa kepegawaian melalui upaya administratif diberlakukan terhadap semua sengketa, terlepas apakah penyelesaian sengketa melalui upaya administratif itu tersedia dan diatur atau tidak dalam peraturan perundang-undangan yang terkait. Norma hukum inilah yang diadopsi oleh UUAP dalam pengaturan mengenai upaya administratif yang merupakan perwujudan asas contrarius actus dimana setiap badan dan/atau pejabat pemerintahan yang menerbitkan keputusan dengan sendirinya juga berwenang untuk membatalkannya.

Undang-undang Administrasi Pemerintahan telah mengelaborasi asas contrarius actus tersebut antara lain melalui batasan upaya administratif sebagaimana dituangkan dalam Pasal 1 angka 16 yaitu proses penyelesaian sengketa yang dilakukan dalam lingkungan administrasi pemerintahan sebagai akibat dikeluarkannya keputusan dan/atau tindakan yang merugikan, dan Pasal 75 ayat (1) yang 
menyatakan bahwa warga masyarakat yang dirugikan terhadap keputusan dan/atau tindakan dapat mengajukan upaya administratif kepada pejabat pemerintahan atau atasan pejabat yang menetapkan dan/atau melakukan keputusan dan/atau tindakan. Dengan demikian, penyelesaian sengketa kepegawaian yang timbul sebagai akibat adanya pemberhentian PNS bukan karena hukuman disiplin, yang selama ini tidak tersedia upaya administratif dalam penyelesaiannya, dapat diselesaikan melalui prosedur upaya administratif berdasarkan UUAP melalui prosedur keberatan kepada pejabat yang menetapkan keputusan dan/atau tindakan, dan banding administratif kepada Badan Pertimbangan Kepegawaian (BAPEK).

2. Kewenangan

Badan

Pertimbangan Kepegawaian (BAPEK) setelah berlakunya Undang-Undang Nomor 30 Tahun 2014 tentang Administrasi Pemerintahan (UUAP).

Undang-Undang Nomor 30

Tahun 2014 tentang Administrasi Pemerintahan merupakan hukum materiil dari sistem peradilan tata usaha negara ${ }^{10}$, sehingga ketentuan-ketentuan dalam undang-undang ini dapat dikatakan memiliki karakter lex specialist dan lex posterior terhadap ketentuan-ketentuan yang termuat Undang-Undang Nomor 5 Tahun 1986 tentang Peradilan Tata Usaha Negara

10 Lihat penjelasan umum UndangUndang Nomor 30 Tahun 2014 tentang Administrasi Pemerintahan.
(UU Peratun) dengan beberapa kali perubahannya, sepanjang mengatur mengenai hal yang sama. Dengan demikian ketentuan materiil mengenai upaya administratif dalam UUAP harus segera direspon oleh UU Peratun sebagai hukum formalnya.

Mahkamah

Agung

Republik Indonesia dalam merespon UUAP tersebut, telah menerbitkan beberapa peraturan diantaranya Peraturan Mahkamah Agung RI Nomor 4 Tahun 2015, Peraturan Mahkamah Agung RI Nomor 5 Tahun 2015 dan Surat Edaran Mahkamah Agung RI Nomor 4 Tahun $2016^{11}$. Salah satu poin penting dari peraturan-peraturan tersebut yang terkait dengan upaya administratif adalah ketentuan bahwa keputusan tata usaha negara yang sudah diperiksa dan diputus melalui upaya banding administratif menjadi kewenangan pengadilan tata usaha negara. Pengaturan ini membawa implikasi hukum terhadap kedudukan keputusan badan/lembaga/majelis upaya administratif (seperti BAPEK) yang tidak lagi disejajarkan dengan putusan yudisial lembaga peradilan administrasi tingkat pertama (PTUN). Hal tersebut menegaskan prinsip bahwa

11 Perma Nomor 4 Tahun 2015 tentang Pedoman Beracara dalam Penilaian Unsur Penyalahgunaan Wewenang; Perma Nomor 5 Tahun 2015 tentang Pedoman Beracara untuk Memperoleh Putusan atas Penerimaan Permohonan Guna Mendapatkan Keputusan dan/atau Tindakan Badan atau Pejabat Pemerintahan; SEMA Nomor 4 Tahun 2016 tentang Pemberlakuan Rumusan Hasil Rapat Pleno Mahkamah Agung Tahun 2016 sebagai Pedoman Pelaksanaan Tugas bagi Pengadilan. 
upaya administratif adalah upaya wakil pemerintah. Dengan demikian,

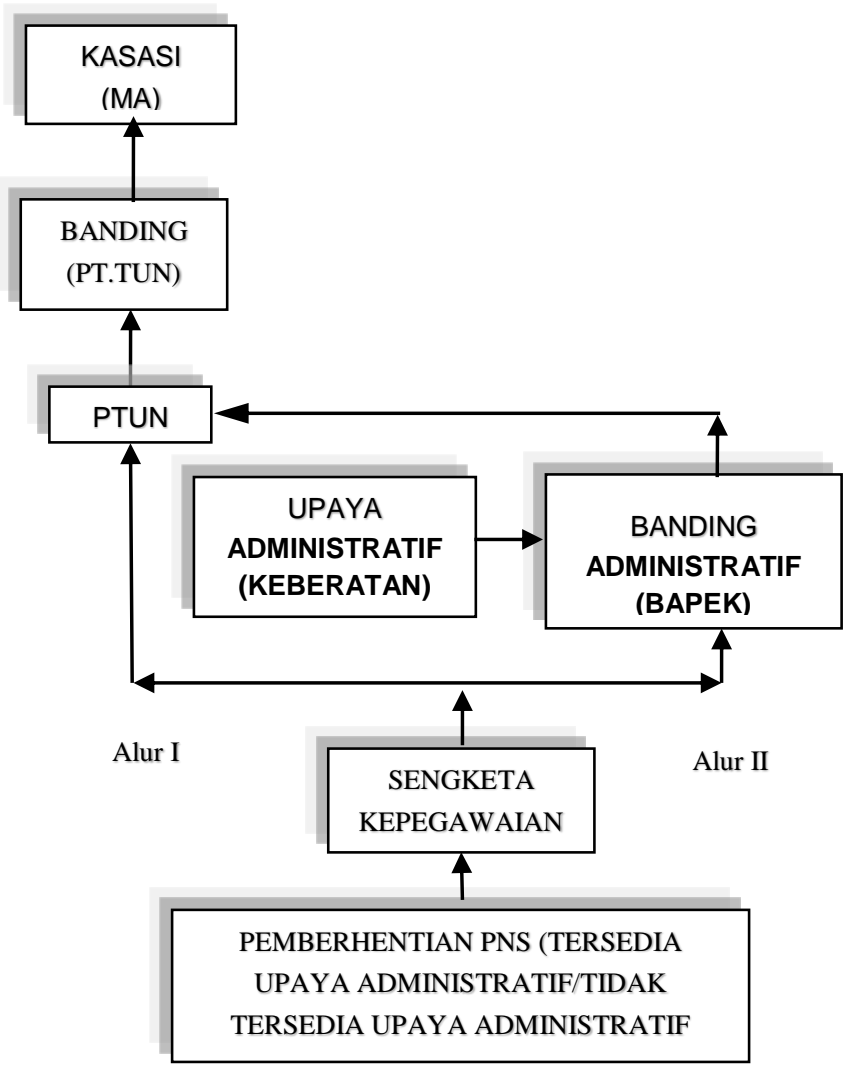
sengketa-sengketa kepegawaian yang timbul sebagai akibat adanya pemberhentian PNS bukan karena hukuman disiplin, seperti pemberhentian PNS yang didasarkan pada beberapa ketentuan dalam Peraturan

Pemerintah Nomor 11 Tahun 2017 tentang Manajemen Pegawai Negeri Sipil ${ }^{12}$,hanya dapat diselesaikan melalui pengajuan gugatan ke pengadilan tata usaha negara penyelesaian sengketa didalam (PTUN) karena tidak tersedia lingkungan pemerintah sendiri (eksekutif) dan terlepas dari kekuasaan lain (legislatif dan yudikatif), sehingga putusannya bukanlah putusan pro penyelesaian melalui upaya administratif, baik melalui prosedur keberatan atau banding administratif. Berlakunya Undang-Undang Nomor 30 yustisiil yang dapat disejajarkan dengan putusan lembaga peradilan.Salah satu kewenangan BAPEK berdasarkan Pasal 3 huruf b Peraturan Pemerintah Nomor 24 Tahun 2011 tentang Badan Pertimbangan Kepegawaian adalah memeriksa dan mengambil keputusan atas banding administratif yang diajukan oleh PNS yang dijatuhi hukuman disiplin berupa pemberhentian dengan hormat tidak atas permintaan sendiri atau pemberhentian tidak dengan hormat sebagai PNS oleh Pejabat Pembina Kepegawaian dan/atau Gubernur selaku

12 Pasal 241 adalah pemberhentian karena adanya perampingan organisasi atau kebijakan pemerintah, Pasal 242 adalah pemberhentian karena dinyatakan tidak cakap jasmani dan/atau rohani, Pasal 247 adalah pemberhentian karena melakukan tindak pidana atau penyelewengan, Pasal 250 adalah pemberhentian karena penyelewengan terhadap Pancasila dan UUD 1945, pemberhentian karena melakukan kejahatan jabatan, pemberhentian karena menjadi anggotadan/atau pengurus partai politik, pemberhentian karena melakukan tindak pidana secara berencana, Pasal 256 adalah pemberhentian karena tidak lagi menjabat sebagai pejabat negara, dan Pasal 257 adalah pemberhentian karena hal lain, misalnya setelah menjalani cuti diluar tanggungan negara atau tugas belajar tidak melaporkan diri. 
Tahun 2014 tentang Administrasi Pemerintahan, telah membuka peluang terhadap semua sengketa administrasi pemerintahan untuk dapat diselesaikan terlebih dahulu melalui upaya administratif, yang dapat ditempuh dengan prosedur keberatan dan banding administratif. Hal tersebut diamanatkan dalam ketentuan Pasal 75 ayat (1) dan ayat (2) UUAP yang menyatakan bahwa warga masyarakat yang dirugikan terhadap keputusan dan/atau tindakan dapat mengajukan upaya administratif kepada pejabat pemerintahan atau atasan pejabat yang menetapkan dan/atau melakukan keputusan dan/atau tindakan melalui keberatan dan banding administratif. Ketentuan ini telah memperluas kompetensi BAPEK untuk menyelesaikan banding administratif atas sengketa-sengketa kepegawaian yang diakibatkan adanya pemberhentian PNS bukan karena hukuman disiplin yang sebelumnya merupakan kewenangan langsung PTUN.

Selengkapnya mengenai alur penyelesaian sengketa kepegawaian karena adanya pemberhentian PNS yang telah memperluas kewenangan BAPEK dalam menangani banding administratif setelah berlakunya UUAP dapat dilihat pada bagan dibawah ini.

Alur penyelesaian sengketa kepegawaian karena adanya pemberhentian PNS setelah berlakunya Undang-Undang Nomor 30 Tahun 2014 tentang Administrasi Pemerintahan.
Keterangan:

1. Alur I adalah alternatif penyelesaian sengketa kepegawaian karena adanya pemberhentian PNS yang tidak tersedia prosedur penyelesaian melalui upaya administratif.

2. Alur II adalah penyelesaian semua sengketa kepegawaian karena adanya pemberhentian PNS, baik tersedia maupun tidak tersedia prosedur penyelesaian melalui upaya administratif.

\section{SIMPULAN DAN SARAN}

1. Simpulan

a) Perlindungan hukum Undang-Undang Nomor 30 Tahun 2014 tentang Administrasi Pemerintahan (UUAP) terhadap PNS yang diberhentikan bukan karena hukuman disiplin, diberikan melalui penyediaan sarana upaya administratif yang terdiri dari keberatan dan banding sebagaimana diatur dalam Pasal 75 sampai dengan Pasal 78 UUAP. Prosedur keberatan diajukan kepada pejabat yang menetapkan keputusan dan banding diajukan kepada Badan Pertimbangan Kepegawaian (BAPEK).

b) Implikasi perlindungan hukum Undang-Undang Nomor 30 Tahun 2014 tentang Administrasi Pemerintahan bagi PNS yang diberhentikan bukan karena hukuman disiplin, terhadap kewenangan Badan Pertimbangan Kepegawaian (BAPEK) adalah 
meluasnya kompetensi/kewenangan

BAPEK untuk menyelesaikan banding administratif yang diajukan oleh PNS yang diberhentikan bukan karena hukuman disiplin sebagaimana diatur dalam Peraturan Pemerintah Nomor 11 Tahun 2017 tentang Manajemen Pegawai Negeri Sipil.

2. Saran

a) Perlu segera dirumuskan peraturan teknis ranah hukum kepegawaian mengenai prosedur pengajuan upaya administratif dengan hukum acaranya yang benar-benar efektif dan memiliki landasan operasional yang kuat sebagai tindak lanjut UU ASN yang diselaraskan dengan semangat Undang-Undang Nomor 30 Tahun 2014 tentang Administrasi Pemerintahan. Pengaturan tersebut dituangkan dalam bentuk Peraturan Pemerintah sebagaimana diamanatkan Pasal 129 UU ASN dan kemudian diperinci lagi melalui peraturan-peraturan atau prosedur teknis di internal Badan Kepegawaian Negara (BKN) dan BAPEK. Dengan demikian, tercipta suatu lembaga upaya administratif yang mampu memberikan perlindungan hukum secara optimal kepada aparatur pemerintah/PNS dalam sengketa kepegawaian.

b) Implikasi perlindungan hukum melalui upaya administratif berdasarkan UUAP terhadap kompetensi BAPEK, harus segera direspon oleh BAPEK meskipun peraturan teknis yang terkait belum ditetapkan oleh pemerintah karena UUAP menetapkan bahwa apabila dalam tenggang waktu 2 (dua) tahun sejak berlakunya undang-undang ini peraturan pemerintah yang dimaksudkan dalam undang-undang ini belum terbit, hakim atau pejabat pemerintahan yang berwenang dapat menjatuhkan putusan atau sanksi administratif berdasarkan undangundang ini. Mendasarkan pada ketentuan tersebut, BAPEK dapat menerima dan menyelesaikan banding administratif yang diajukan oleh PNS yang diberhentikan bukan karena hukuman disiplin

\section{DAFTAR PUSTAKA}

Philipus M. Hadjon, Tatiek Sri Djatmiati, 2016. "Argumentasi Hukum (Legal Argumentation/Legal Reasoning), Langkah-langkah Legal Problem Solving dan Penyusunan Legal Opinion, Yogyakarta: Gadjah Mada University Press.

Werner Menski, 2015. Comparative Law In Global Context (Terjemahan M. Khozim). Bandung: Penerbit Nusa Media.

Hans Kelsen, 2015. General Theory of Law and State (Terjemahan Raisul Muttaqien). Bandung: Penerbit Nusa Media.

Anton F. Susanto, 2015. Penelitian Hukum, TransformatifPartisipatoris. Malang: Setara Press.

Philipus M. Hadjon, 2015. "Kebutuhan Akan Administrasi Umum", dalam Muhadi (editor), Hukum Administrasi dan Good 
Governance. Jakarta: Penerbit Universitas Tri Sakti.

Soerjono Soekanto dan Sri Mamudji, 2014. Penelitian Hukum Normatif. Jakarta: PT. Raja Grafindo Persada.

Sjachran Basah, 2014. Eksistensi dan Tolok Ukur Badan Peradilan Admnisitrasi di Indonesia, Bandung: PT. Alumni.

Sri Hartini, Setiajeng Kadarsih dan Tedi Sudrajat. $2014 . \quad$ Hukum Kepegawaian di Indonesia. Jakarta: Sinar Grafika.

Munir Fuady, 2014. Teori-Teori Besar (Grand Theory) Dalam Hukum. Jakarta: Kencana PrenadaMedia Group.

Sudikno Mertokusumo, 2014. Perbuatan Melawan Hukum Oleh Pemerintah. Yogyakarta: Cahaya Atma Pustaka.

Achmad Ali dan Wiwie Heryani, 2013. Menjelajahi Kajian Empiris Terhadap Hukum. Jakarta: Kencana PrenadaMedia Group.

Ridwan HR, 2013. Hukum Administrasi Negara. Jakarta:RajaGrafindo Persada.

Endang Widyastuti, 2012. Pedoman Penulisan Usul Penelitian, Tesis dan Artikel IImiah. Purwokerto: Program Pascasarjana Unsoed.

CST. Kansil dan Christine ST Kansil, 2010. Perbandingan Hukum Administrasi Negara. Jakarta: Rineka Cipta.

Ridwan, 2009. Tiga Dimensi Hukum Administrasi dan Peradilan Administrasi. Yogyakarta: FH UII Press.

Siti Soetami, 2009. Hukum Acara Peradilan Tata Usaha Negara, Cet. Ke-6, Bandung: Refika Aditama.

Pipit Rochijat Kartawidjaja, 2006. Pemerintah Bukanlah Negara: Studi Komparasi Administrasi Pemerintah $R I$ dengan Jerman. Surabaya: Henk Publishing.

Indroharto, 2005. Usaha Memahami Undang-Undang tentang Peradilan Tata Usaha Negara. Buku II. Beracara di Pengadilan Tata Usaha Negara (Edisi Baru). Jakarta: Pustaka Sinar Harapan.

Titon Slamet Kurnia, 2005. Reparasi (Reparation) terhadap Korban
Pelanggaran HAM di Indonesia, Bandung: PT. Citra Aditya Bakti.

Suparto Wijoyo, 2005. Karakteristik Hukum Acara Peradilan Administrasi (Peradilan Tata Usaha Negara). Surabaya: Airlangga University Press.

RM. AB. Kusuma, 2004. Lahirnya Undang-Undang Dasar 1945, Jakarta: Badan Penerbit Fakultas Hukum Universitas Indonesia.

K.C. Wheare, 2003. KonstitusiKonstitusi Modern (Modern Constitutions), (Penerjemah: Muhammad Hardani). Surabaya: Pustaka Eureka.

S.F. Marbun, 2003. Peradilan Administrasi dan Upaya Administratif di Indonesia. Yogyakarta: Liberty.

Zairin Harahap, 2002. Hukum Acara Peradilan Tata Usaha Negara, Edisi Revisi. Jakarta: PT. RajaGrafindo Persada.

R. Wiyono, 2002. Hukum Acara Peradilan Tata Usaha Negara (Edisi 3). Jakarta: Sinar Grafika.

S.F. Marbun, 2001. Dimensi-Dimensi Pemikiran Hukum Administrasi Negara. Yogyakarta: UII Press.

Indroharto, 2000. Usaha Memahami Undang-Undang tentang Peradilan Tata Usaha Negara. Buku I. Beberapa Pengertian Dasar Hukum Tata Usaha Negara (Edisi Baru). Jakarta: Pustaka Sinar Harapan.

J.J. H. Bruggink, 1999. Refleksi Tentang Hukum (alih bahasa: Arief Sidharta). Bandung: Citra Aditya Bakti.

Philipus M. Hadjon, dkk. 1997. Pengantar Hukum Administrasi Indonesia. Yogyakarta: Gadjah Mada University Press.

Carol Harlow and Richard Rawlings, 1997. Law and Administration, Second Edition. London: Butterworth.

Nasution, Adnan Buyung, 1995. Aspirasi Pemerintahan Konstitusional di Indonesia: Studi Sosio Legal atas Konstituante 1956-1959, Jakarta: Pustaka Utama Grafiti.

Azhary. 1995. Negara Hukum Indonesia, Analisis Yuridis Normatif Tentang UnsurUnsurnya. Jakarta: UI-Press. 
999 | Jurna I I dea Hukum

VoI. 4 No.2 Oktober 2018

Magister Hukum Fakultas Hukum

Universitas Jenderal Soedirman

Lubis, Todung Mulya, 1993. Hak-hak Asasi Manusia dalam Masyarakat Dunia, Isu dan Tindakan, Jakarta: Yayasan Obor Indonesia.

Lubis, Todung Mulya, 1993. In Search of Human Rights: Legal-Political Dilemmas of Indonesia's New Order 1966-1990, Jakarta: Gramedia Pustaka Utama.

Baharudin Lopa dan Andi Hamzah, 1991. Mengenal Peradilan Tata Usaha Negara. Jakarta: Sinar Grafika.

Utrecht, E, 1988. Pengantar Hukum Administrasi Negara Indonesia. Surabaya: Pustaka Tinta Mas.

Philipus M. Hadjon, 1987. Perlindungan Hukum Bagi Rakyat di Indonesia, Sebuah Study tentang Prinsipprinsipnya, Penanganannya oleh Pengadilan dalam Lingkungan Peradilan Umum dan Pembentukan Peradilan Administrasi Negara, Surabaya: PT. Bina Ilmu.

Rai Sri Dewi, Ida Ayu, 1999. Analisis Efektifitas Badan Pertimbangan Kepegawaian sebagai Lembaga Banding Administratif dalam Rangka Pengawasan Administratif. Tesis. Universitas Indonesia, Jakarta

Ichtiar Prambudi, 2016. Analisis Peranan Badan Pertimbangan Kepegawaian Untuk Menyelesaikan Sengketa Kepegawaian Akibat Terkena Sanksi Bagi Pegawai Negeri Sipil. Tesis. Fakultas Hukum, Universitas Sebelas Maret, Surakarta. (tidak dipublikasikan).

Sayuti, 2011. Konsep Rechtsstaat dalam Negara Hukum Indonesia, Kajian Terhadap Pendapat Azhary. Nalar Fiqh. 4 (2)

Sri Hartini, 2011. Upaya Keberatan Terhadap PNS Yang Dijatuhi Hukuman Pemberhentian Tidak Dengan Hormat. Jurnal Dinamika Hukum, 11 (2)

Kartono, 2016. Pengaruh UndangUndang Nomor 30 Tentang Administrasi Pemerintahan terhadap Sistem Peradilan Tata Usaha Negara. Makalah disampaikan dalam Diskusi Paralel Bidang HAN Musyawarah
Daerah Asosiasi Pengajar HTNHAN Wilayah Jawa Tengah, Cisarua, Bogor, 14-16 Oktober 2016.

Eko Prasojo, 2011. (Rancangan) Undang-Undang Administrasi Pemerintahan untuk Pembangunan Hukum Administrasi Negara dan Penciptaan Good Governance. Makalah disampaikan dalam Bimbingan Teknis bagi Hakim di Lingkungan PTUN dengan tema Pembaharuan Peradilan Di Lingkungan Peradilan Tata Usaha Negara Dalam Kaitannya Dengan Reformasi Birokrasi Pemerintahan, Jakarta, 31 Maret 2 April 2011. 